\title{
New methods for preparing mercury-based ferrofluids
}

\author{
Linderoth, Søren; Rasmussen, L.H.; Mørup, Steen
}

Published in:

Journal of Applied Physics

Link to article, DOI:

10.1063/1.348124

Publication date:

1991

Document Version

Publisher's PDF, also known as Version of record

Link back to DTU Orbit

Citation (APA):

Linderoth, S., Rasmussen, L. H., \& Mørup, S. (1991). New methods for preparing mercury-based ferrofluids. Journal of Applied Physics, 69(8), 5124-5126. https://doi.org/10.1063/1.348124

\section{General rights}

Copyright and moral rights for the publications made accessible in the public portal are retained by the authors and/or other copyright owners and it is a condition of accessing publications that users recognise and abide by the legal requirements associated with these rights.

- Users may download and print one copy of any publication from the public portal for the purpose of private study or research.

- You may not further distribute the material or use it for any profit-making activity or commercial gain

- You may freely distribute the URL identifying the publication in the public portal

If you believe that this document breaches copyright please contact us providing details, and we will remove access to the work immediately and investigate your claim 


\title{
New methods for preparing mercury-based ferrofluids
}

\author{
S. Linderoth, L. H. Rasmussen, and S. Mørup \\ Laboratory of Applied Physics, Technical University of Denmark, DK-2800 Lyngby, Denmark
}

Metallic ferrofluids based on magnetic particles in mercury have been produced by two new methods. Alloy particles of $\mathrm{Fe}-\mathrm{B}, \mathrm{Fe}-\mathrm{Co}-\mathrm{B}, \mathrm{Fe}-\mathrm{Ni}-\mathrm{B}$, and $\mathrm{Co}-\mathrm{B}$ were prepared by reduction of the transition metal ions in aqueous solutions by $\mathrm{NaBH}_{4}$ and subsequently suspended in mercury. In one preparation, the metallic mercury was added to the solution with precipitates and in another method produced simultaneously with the precipitates by reduction of mercury ions to metallic mercury. The samples were characterized by magnetization and Mössbauer spectroscopy measurements.

\section{INTRODUCTION}

Ferrofluids are magnetic liquids that consist of ultrasmall ferro- or ferrimagnetic particles suspended in a liquid carrier. ${ }^{1,2}$ The carrier liquid is typically an organic liquid or water and the magnetic particles are typically maghemite or magnetite. Metallic ferrofluids have the advantage that they àre excellent electronic and heat conductors, which may be utilized in, e.g., heat exchangers and for more efficient cooling in rotating shafts. ${ }^{3}$

Metallic ferrofluids based on mercury as the carrier and small iron or cobalt particles in suspension have been studied for many years. ${ }^{4,5}$ Two methods have, up to now, been utilized for preparing these ferrofluids. One method has been to reduce transition metal ions in aqueous solution to the metallic state by using the reducing ability of sodium in sodium amalgam with simultaneous incorporation of the transition metal atom in the amalgam. ${ }^{4}$ The second method is to electroplate the transition metal ions into a mercury cathode under vigorous stirring. ${ }^{5}$ Ultrasmall ferromagnetic particles are thereby formed. ${ }^{3-8}$ The particles have, in the case of iron, earlier been assumed to be $\alpha$-Fe particles, but recent Mössbauer spectroscopy studies of such ferrofluids have revealed that probably metastable $\mathrm{Fe}-\mathrm{Hg}$ alloy particles have been formed. ${ }^{6,8,9}$

We report here on two new methods for preparing metallic ferrofluids. The ferrofluids are still based on mercury as the metallic carrier liquid and on reduction of transition metal ions to the metallic state, but the ions are now reduced to the metallic state by use of an alkali-metal borohydride in aqueous solution. The magnetic particles prepared by this method have diameters in the range 10-200 nm (Refs. 10-12) and they may be amorphous due to incorporation of boron during the reduction. ${ }^{11-13}$ Magnetization and Mössbauer spectroscopy measurements have been used for studies of the prepared ferrofluids.

\section{EXPERIMENT}

In the first series of preparations (method $A$ ) Fe-B, Fe-Co-B, Fe-Ni-B, Co-B, and Ni-B particles were produced by dropwise addition of an aqueous solution of $\mathrm{NaBH}_{4}(100 \mathrm{ml} ; 0.2 \mathrm{M})$ to an aqueous solution of transition metal ions ( $200 \mathrm{ml} ; 0.2 \mathrm{M}$ ). Five solutions with transition metal ions were prepared with the compositions: (1) $100 \% \mathrm{Fe}$; (2) $80 \% \mathrm{Fe}, 20 \% \mathrm{Co}$; (3) $80 \% \mathrm{Fe}, 20 \% \mathrm{Ni}$; (4) $100 \% \mathrm{Co}$; and (5) $100 \% \mathrm{Ni}$. The salts used were
$\mathrm{FeSO}_{4}, \mathrm{CoCl}_{2}$, and $\mathrm{NiCl}_{2}$. Black precipitates were formed and metallic mercury was then added to the slurry and mixed with the precipitates with the purpose to suspend the particles in the mercury.

Magnetization measurements on samples prepared by method A were performed at $295 \mathrm{~K}$ employing a conventional vibrating-sample magnetometer.

Two other preparations were performed with another method (method B) by which the iron ions were obtained by dissolving metallic iron in concentrated $\mathrm{HCl}$. A mercury salt $\left(\mathrm{HgCl}_{2}\right)$ was then dissolved in the solution, whereafter drops of aqueous solutions of concentrated $\mathrm{NaOH}$ were added to obtain a $\mathrm{pH}$ of about 3 in the salt solutions. In the first preparation $12.5 \mathrm{ml}$ of $0.2-\mathrm{M}$ $\mathrm{NaBH}_{4}$ in aqueous solution was added dropwise to $7.5 \mathrm{ml}$ of $0.2-\mathrm{M}$ salt solution $(0.195-\mathrm{M} \mathrm{Hg}$ and $0.005-\mathrm{M} \mathrm{Fe})$. A second preparation was also performed with Co ions in the salt solution. Here $17 \mathrm{ml}$ of $0.2-\mathrm{M} \mathrm{NaBH}_{4}$ in aqueous solution was added to $10 \mathrm{ml}$ of $0.2-\mathrm{M}$ salt solution (0.195-M $\mathrm{Hg}, 0.003-\mathrm{M} \mathrm{Fe}$, and $0.002-\mathrm{M} \mathrm{Co}$ ). By both preparations metallic mercury and a black precipitate were formed, which were then mixed to result in ferrofluids.

In method $\mathrm{B}$ the iron metal dissolved in $\mathrm{HCl}$ was $90 \%$ ${ }^{57} \mathrm{Fe}$ in order to make it possible to perform Mössbauer spectroscopy studies on the samples. These ferrofluids were made into thin films by squeezing a droplet of the ferrofluid and, subsequently, freezing the films in liquid nitrogen. The samples were studied at 12,80 , and $220 \mathrm{~K}$ by Mössbauer spectroscopy. The Mössbauer spectroscopy measurements were performed using a constant acceleration spectrometer with a ${ }^{57} \mathrm{Co}$ source in rhodium. The velocity scale was calibrated by measurements on a $12.5-\mu \mathrm{m} \alpha-\mathrm{Fe}$ foil at $295 \mathrm{~K}$. The isomer shifts are given relative to $\alpha-\mathrm{Fe}$ at 295 K.

\section{RESULTS AND DISCUSSION}

It was found that the Fe-Ni-B, Co-B, and Ni-B particles prepared by method $A$ were readily suspended in mercury. With increasing concentration of metal particles the produced amalgam changed from a liquid to a paste-like state. The viscosity could be decreased again by addition of mercury. The $\mathrm{Fe}-\mathrm{B}$ and $\mathrm{Fe}-\mathrm{Co}-\mathrm{B}$ particles prepared by method A could not be suspended in mercury.

None of the precipitates entered the mercury if they were washed in destilled water prior to mixing with mer- 


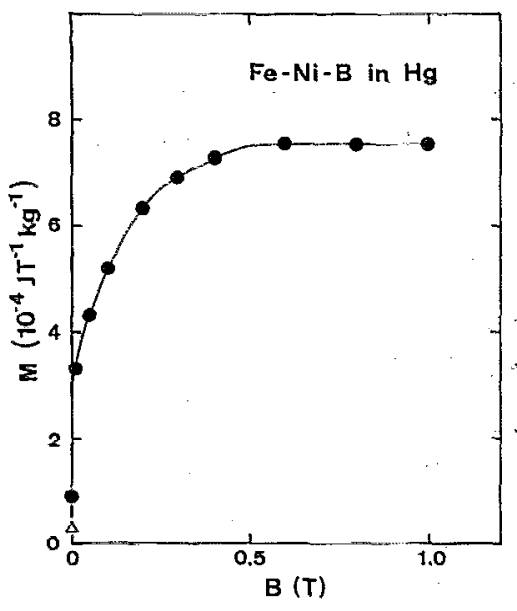

FIG. 1. Magnetization vs applied field for $\mathrm{Fe}-\mathrm{Ni}-\mathrm{B}$ in mercury. The measurements were performed at $295 \mathrm{~K}$, starting with maximum applied field. The triangle shows the magnetization at zero field $5 \mathrm{~min}$ after the zero field was reached.

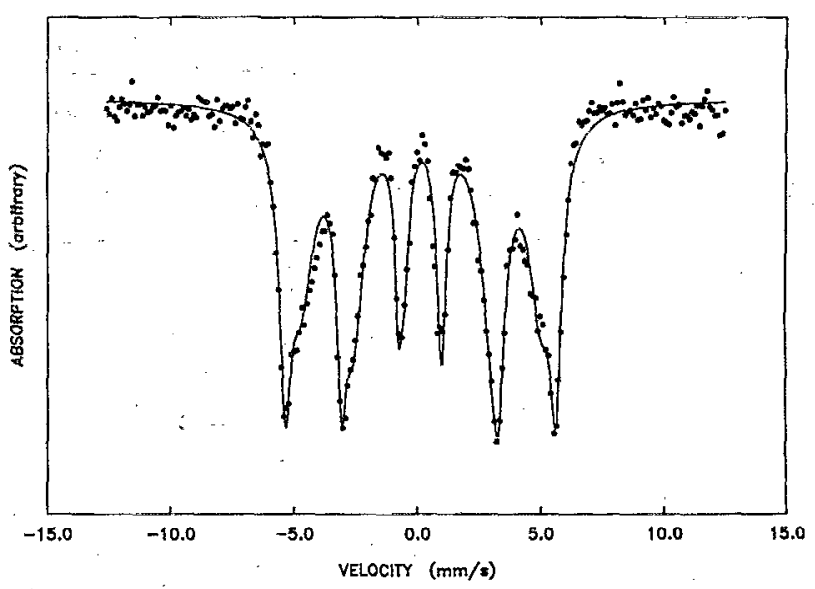

FIG. 2. Mössbauer spectrum, obtained at $80 \mathrm{~K}$, for the Fe-B amalgam prepared by mcthod $\mathrm{B}$.

increases rapidly is for pure $\mathrm{Fe}$ particles in mercury around 1.0 wt. $\% .^{3}$

Mössbauer spectra, obtained at $80 \mathrm{~K}$, of the ferrofluids prepared by method B, are shown in Figs. 2 and 3. Both spectra are seen to be magnetically split. The spectrum of the Fe-B amalgam (cf. Fig. 2) may be described by two sextets; one with sharp absorption lines, a magnetic hyperfine field of $34.1 \pm 0.5 \mathrm{~T}$, an isomer shift of $0.12 \pm 0.03$ $\mathrm{mm} \mathrm{s}^{-1}$, and constituting about $30 \%$ of the spectral area-and another sextet with broad absorption lines, a magnetic hyperfine field of $30.2 \pm 1.5 \mathrm{~T}$ and an isomer shift of $0.19 \pm 0.03 \mathrm{~mm} \mathrm{~s}^{-1}$. The former component is due to $\alpha-\mathrm{Fe}$, while the latter component may be ascribed to amorphous $\mathrm{Fe}-\mathrm{B}$. From the magnetic hyperfine field the boron content can be estimated to be about $10-15$ at. $\%{ }^{17}$ The reason that the precipitate is partly crystalline in this case is probably that the $p \mathrm{H}$ varied between 3 and 9 during the reaction. When the precipitates are formed at $p \mathrm{H}$ values below 5 they have been reported to be partly crystalline and partly amorphous. ${ }^{18}$

with particle concentrations just below the critical concentration of rapidly increasing viscosity. The magnetization vs field curve obtained at $295 \mathrm{~K}$ for the Fe-Ni-B amalgam is shown in Fig. 1. The curve was measured by decreasing the applied field from $1.0 \mathrm{~T}$ to zero. The magnetization did not reach zero at zero field but a time dependence was found with the magnetization approaching zero. This shows that the particles probably have formed clusters or chains such that the particles feel resistance against rotation in the mercury. The magnetization vs field curve for the Co-B amalgam sample looked similar to that in Fig. 1.

The saturation magnetizations of the $\mathrm{Fe}-\mathrm{Ni}-\mathrm{B}$ and Co-B amalgam samples were found to be $7.5 \times 10^{-4}$ $\mathrm{J} \mathrm{T}^{-1} \mathrm{~kg}^{-1}\left(7.5 \times 10^{-4} \mathrm{emu} / \mathrm{g}\right)$ and $36.7 \times 10^{-4}$ $\mathrm{J} \mathrm{T}^{-1} \mathrm{~kg}^{-1}$, respectively. Assuming the saturation magnetization for $\mathrm{Fe}, \mathrm{Co}$, and $\mathrm{Ni}$ to be 2.2-, 1.7-, and 0.6-Bohr magnetons, respectively, i.e., neglecting the influence of the boron and the mercury on the magnetic moments, the Fe$\mathrm{Ni}-\mathrm{B}$ and Co-B amalgam ferrofluids are estimated to contain approximately 0.4 and $2.3 \mathrm{wt}$ \% magnetic particles, respectively. The critical concentration where the viscocity

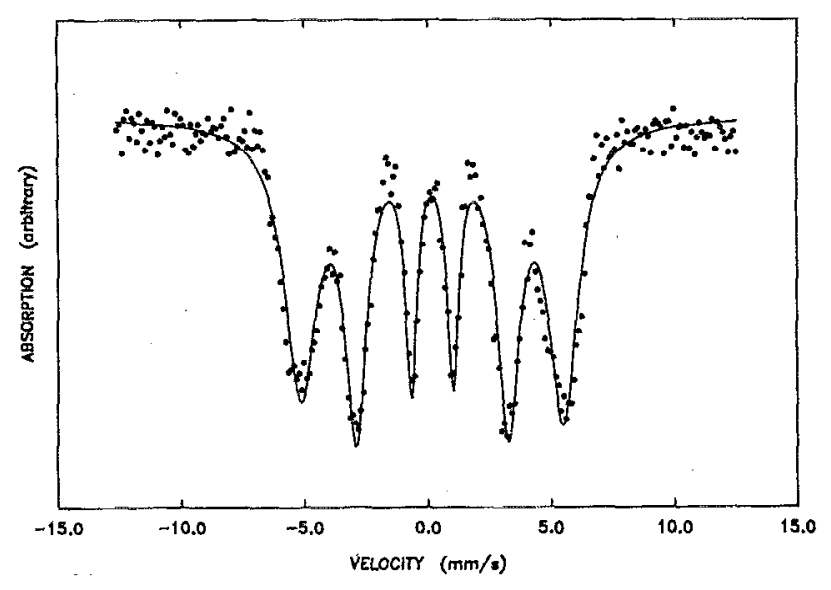

FIG. 3. Mössbauer spectrum, obtained at $80 \mathrm{~K}$, for the Fe-Co-B amalgam prepared by method B. 
The spectrum of the $\mathrm{Fe}-\mathrm{Co}-\mathrm{B}$ amalgam may be described by one sextet with broad lines with a magnetic hyperfine field of about $33.0 \mathrm{~T}$, an isomer shift of 0.19 $\mathrm{mm} \mathrm{s}^{-1}$, and a negligible qaudrupole shift. This component may be an $\mathrm{Fe}-\mathrm{Co}$ alloy, ${ }^{19}$ but it may also be an $\mathrm{Fe}$ Co-B alloy, possibly an amorphous alloy. The $p \mathrm{H}$ during the reaction has also for $\mathrm{Fe}$-Co aqueous solutions been found to be important for the resulting composition and whether or not the precipitate become amorphous. ${ }^{20}$

Measurements at $220 \mathrm{~K}$ showed slightly decreased magnetic hyperfine fields, while the measurements at $12 \mathrm{~K}$ yielded spectra very similar to those obtained at $80 \mathrm{~K}$. It can therefore be concluded that the component with a hyperfine field of 38-40 T, obtained from measurements on Fe-Hg systems prepared by the conventional methods, ${ }^{6,8}$ is not present in the samples prepared by the method presented herc. Hence the Fe secms not to have alloyed with the mercury.

\section{CONCLUSIONS}

Two new ways of producing metallic ferrofluids have been presented. The magnetic particles of $\mathrm{Fe}, \mathrm{Co}, \mathrm{Ni}$, and $\mathrm{B}$ alloys were produced by reduction of the transition metal ions in aqueous solution by $\mathrm{NaBH}_{4}$. Fe-B, $\mathrm{Fe}-\mathrm{Co}-\mathrm{B}$, $\mathrm{Fe}-\mathrm{Ni}-\mathrm{B}$, and $\mathrm{Co}-\mathrm{B}$ amalgam ferrofluids were prepared by the methods. Also, Ni-B could easily be suspended in mercury but was nonmagnetic at room temperature. At least 2 wt. \% magnetic particles could be suspended in the case of $\mathrm{Co}-\mathrm{B}$ amalgams. The $\mathrm{Fe}-\mathrm{Hg}$ alloy which is formed when amalgams have been prepared by more conyentional means was not observed here.

\section{ACKNOWLEDGMENTS}

O. V. Nielsen is acknowledged for assistance with the magnetization measurements, and the Danish Council for Technical Research for support.

${ }^{1}$ S. W. Charles and J. Popplewell, in Ferromagnetic Materials, edited by E. P. Wohlfarht (North-Holland, Amsterdam, 1980), Vol. 2, p. 509.

${ }^{2}$ R. E. Rosensweig, Chem. Eng. Progress, 53 (April 1989).

${ }^{3}$ S. R. Hoon, S. W. Charles, and J. Popplewell, Technical Report, University College of North Wales, Bangor (1980), p. 63.

${ }^{4}$ A. Mayer and E. Vogt, Z. Naturforsch. Teil 7, A 334 (1952).

${ }^{5}$ R. B. Falk and F. E. Luborsky, Trans. Metall. Soc. AIME 233, 2079 (1965).

${ }^{6}$ S. Linderoth, S. Mørup, A. Meagher, S. Wells, J. van Wonterghem, H. K. Rasmussen, and S. W. Charles, J. Phys. (Paris) Colloq. 49, C8-1827 (1988).

${ }^{7}$ L. Takács, J. Appl. Phys. 63, 4264 (1988).

${ }^{8}$ S. Linderoth and S. Morup, J. Appl. Phys. 67, 4496 (1990).

${ }^{9} \mathrm{~J}$. van Wonterghem, S. Mørup, S. W. Charles, and S. Wells, J. Magn. Magn. Mater. 65, 276 (1987).

${ }^{10}$ S. G. Kim and J. R. Brock, J. Colloid Interface Sci, 116, 431 (1987),

${ }^{11}$ S. Linderoth, S. Mørup, A. Meagher, J. Larsen, M. D. Bentzon, B. S. Clausen, C. J. W. Koch, S. Wells, and S. W. Charles, J. Magn. Magn. Maler. 82, 138 (1989).

${ }^{12}$ L. Yiping, G. C. Hadjipanayis, C. M. Sorensen, and K. J. Klabunde, J. Magn. Magn. Mater. 79, 321 (1989).

${ }^{13}$ J. van Wonterghem, S. M 6 rup, C. J. W. Koch, S. W. Charles, and S. Wells, Nature 322, 622 (1986).

${ }^{14}$ M. Hansen, Constitution of Binairy Alloys (McGraw-Hill, New York, 1958).

${ }^{15}$ M. Sostarich, S. Dey, P. Deppe, M. Rosenberg, G. Czjzek, V. Oestreich, H. Schmidt, and F. E. Luborsky, IEEE Trans. Magn. MAG-17, 2612 (1981):

${ }^{16}$ S. Mørup, J. van Wonterghem, A. Meagher, and C. J. W. Koch, IEEE Trans. Magn. MAG-23, 2978 (1987).

${ }^{17}$ T. Kemeny, I. Vincze, B. Fogarassy, and S. Arajs, Phys. Rev. B 20, 476 (1979).

${ }^{18}$ S. Linderoth and S. Morup, J. Appl. Phys. 67, 4472 (1990).

${ }^{19}$ C. E. Johnson, M. S. Ridout, and T. E. Cranshaw, Proc. Phys. Soc. 81, 1079 (1963)

${ }^{20}$ S. Linderoth, S. Mørup, and M. D. Bentzon, J. Magn. Magn. Mater. 83, 457 (1990). 